\title{
Vad händer om vi legaliserar narkotika?
}

\section{TED GOLDBERG}

Enligt den dominerande förklaringsmodellen i Sverige är problematisk konsumtion av narkotika huvudsakligen ett resultat av drogernas biokemiska (beroendeframkallande) egenskaper. Med utgångspunkt i detta synsätt tror vi oss veta att legalisering/avkriminalisering obönhörligen skulle leda till ökat missbruk - och därmed ökad misär. Eftersom vi redan "vet" svaret finns ingen anledning att föra en "legaliseringsdebatt". Men utifrån en psykosocial förståelse av narkotikaproblemet kan slutsatsen bli en annan.

I denna artikel argumenterar jag för att ingen med säkerhet kan förutspå vad som kommer att hända om Sverige skulle legalisera/avkriminalisera narkotika. Detta belyses genom att sammanfatta argument för respektive emot att vi kommer att få en väsentlig ökning av antalet problematiska konsumenter ifall vi överger prohibition som narkotikapolitisk modell. Min slutsats är att för att bygga drogpolicy på kunskap i stället för tro måste vi vara beredda att experimentera med olika drogpolitiska åtgärder.

I stora delar av världen pågår en livlig debatt om huruvida narkotika ska legaliseras alternativt avkriminaliseras. För att ta några exempel är avkriminalisering officiell politik i Nederländerna, Portugal och Tjeckien. I år kommer flera amerikan- ska delstater att folkomrösta om att legalisera rekreationskonsumtion av cannabis, och Köpenhamns kommunfullmäktige har redan sagt ja till detta. "The Latin American Commission on Drugs and Democracy", där bl.a. tre f.d. latinamerikanska presidenter ingick, deklarerade öppet att kriget mot narkotikan har misslyckats. Bland problemen de poängterar är de enorma sociala kostnaderna, hoten mot demokratiska institutioner, ökad organiserad brottslighet, den växande kontroll som kriminella grupperingar har över lokala marknader och markområden, drogmarknadsrelaterat våld samt korruption. (Latin American Commission on Drugs and Democracy, 2010, s 5)

Hittills har den internationella legaliseringsdebatten, där ovanstående idéer ingår, fått mycket lite uppmärksamhet i Sverige. Av utrymmesskäl koncentrerar jag mig på bara en fråga: om Sverige skulle legalisera/ avkriminalisera narkotika kommer detta att leda till en väsentlig ökning av problematisk konsumtion i vårt land?

\section{Några definitioner}

I den vetenskapliga litteraturen kallas det drogpolitiska paradigmet som länge varit 
dominerande i t.ex. FN och Sverige, prohibition, efter engelskans "prohibit" (förbjuda). Prohibition som drogpolitiskt paradigm tar sin utgångspunkt i att all icke-medicinsk konsumtion av narkotika är förbjuden enligt lag. I prohibitionsländer talar man om "nolltolerans" mot droger och i Sverige används parollen "ett narkotikafritt samhälle" som synonym.

I drogsammanhang betyder inte "legalisering" samma sak för alla människor. För somliga tycks begreppet innebära att alla psykoaktiva droger ska släppas helt fria, dvs. att varje människa får när och hur som helst göra som de själva vill med samtliga psykoaktiva substanser. För andra har legalisering en betydligt mer begränsad innebörd - exempelvis att det blir tillåtet att inneha, konsumera samt ev. producera och/ eller sälja någon/några drog(er) som hittills varit illegal(a) - men samtidigt ska samtliga led kringgärdas av regleringar.

Mig veterligen finns ingen forskare som menar att vi ska släppa alla psykoaktiva droger helt fria. Denna tolkning har bara använts av människor som inte ens kan tänka sig överväga någon annan narkotikapolitisk modell än prohibition. Därför kommer inte frisläppande att diskuteras här. I stället betraktas legalisering som en övergång från dagens förbud till andra tänkbara regleringar. Kort sagt med legalisering menar jag att innehav, konsumtion, samt eventuellt produktion och/eller försäljning av en eller flera psykoaktiva substanser stryks från ett lands brottsbalk. I stället kontrolleras dessa droger genom andra typer av regelverk, exempelvis liknande dem som finns för läkemedel, alkohol och tobak.
Även "avkriminalisering" används på olika sätt av olika forskare. Här finns inte utrymme att presentera alternativa modeller utan jag nöjer mig med den som kommer att användas här. Den grundläggande tanken bakom avkriminalisering är att minska narkotikapolitikens repressiva verkningar, samtidigt som man håller fast vid kravet i FN-drogkonventionerna att narkotikan lagligen är förbjuden. Därigenom skapar man en mer human narkotikapolitik samtidigt som man minskar kritiken från prohibitionsländerna. Avkriminalisering innebär att vissa typer av befattning med narkotika förblir brott men regleras genom t.ex. administrativa eller medicinska åtgärder. Detta kan åstadkommas genom att modifiera lagstiftningen och/eller ändra dess tillämpning. Det finns flera olika tillvägagångssätt för att göra detta. En är ned kriminalisering (eng. = depenalisation) som innebär att man väljer att lagstifta om och/eller döma till mildare påföljder, t.ex. korta(re) fängelsestraff (företrädesvis villkorlig), böter, vård, samtal, utbildning, samhällstjänst osv. I möjligast mån undviker man döma till hårda straff, t.ex. att sitta $i$ fängelse (eng. $=$ diversion). Den portugisiska narkotikapolitiken utgör ett exempel på avkriminalisering i denna bemärkelse. Metoden används i viss mån även i Sverige. Så t.ex. är det vanligt att hänvisa unga människor som ertappas med mindre mängder cannabis till socialtjänsten.

En annan typ av avkriminalisering bygger på att man har en uttalad policy om att inte beivra narkotikabrott under vissa omständigheter. Detta kan man åstadkomma t.ex. genom att polisen har som praxis att inte arrestera människor som bryter mot vissa 
delar av narkotikalagstiftningen, eller genom att åklagarna regelmässigt beviljar åtalsunderlåtelse. Därigenom undviker man att stämpla drogkonsumenter som avvikare - om inte de gör sig skyldiga till andra typer av brott. Förfaringssättet beskrivs genom begreppen de jure (lagen-ilagboken) och de facto (lagen-i-praktiken). Denna typ av avkriminalisering innebär att de jure och de facto inte behöver vara samma sak. Nederländsk drogpolicy är ett exempel på avkriminalisering i denna bemärkelse. Den nederländska regeringen har utfärdat riktlinjer som klargör under vilka förutsättningar narkotikabrott inte ska beivras.

En problematisk konsument är en människa som prioriterar en psykoaktiv substans (oavsett vilken) så högt att den blir till det som Fingarette (1989, s 101f) kallar en central aktivitet. Drogen tillåts spela en dominerande roll i individens vardag. Livsaspekter som de flesta människor ger företräde åt, t.ex. familjen, sociala relationer, arbete, ekonomi, hälsa, osv. prioriterar problematiska konsumenter lågt jämfört med droger.

Däremot betraktar inte rekreationskonsumenter psykoaktiva substanser som en central aktivitet. Droger är en av många saker som man ägnar sig åt - men inte den viktigaste. Rekreationskonsumenter underordnar drogkonsumtionen andra värderingar, verksamheter och mänskliga relationer. (Peele, 1998, s 8) De använder psykoaktiva substanser men låter inte dessa dominera livet. De kan finna värde i aktiviteter utan droger och de uppvisar ingen synbar abstinens när de inte har psykoaktiva substanser i kroppen.
Ett annat sätt att uttrycka skillnaden mellan dessa två sätt att använda psykoaktiva substanser är att poängtera att för problematiska konsumenter har droger ett eget värde - dvs. drogkonsumtion behöver inte kopplas till någon annan aktivitet. Däremot brukar rekreationskonsumenter använda droger för att få ut ett mervärde ur andra aktiviteter. Den kanadensiska forskaren Cameron Duff menar att nöjen i samband med droger primärt är ett resultat av de aktiviteter som substanserna underlättar. Droger upplevs som ett hjälpmedel att" vara i världen" på sätt som är svåra att uppnå $i$ nyktert tillstånd. (Duff, 2008, s 386, 388f) Exempelvis kan man ta narkotika i samband med en fest därför att man upplever att det därigenom blir lättare att prata med andra människor, att dansa, att inleda en sexuell kontakt, osv. - och därmed blir festen roligare. Att många svenskar använder alkohol i sådana syften är allmänt accepterat. Men tanken att även narkotika kan fylla denna funktion har inte vunnit gehör i stora kretsar i Sverige (men väl i en rad andra länder, som Australien, Spanien, Storbritannien och USA).

\section{Vad talar för att legalisering/ avkriminalisering leder till en väsentlig ökning av problematisk konsumtion?}

\section{Biokemisk teori}

Om samhället skulle utveckla en mer tolerant attityd till narkotikan skulle det bli lättare för flera att använda dessa substanser. Detta beror på att drogkonsumtion i så 
fall inte skulle betraktas som ett allvarligt normbrott, och därmed skulle flera människor inte längre uppleva att det strider mot deras självbild att använda dessa substanser. Därför verkar det rimligt att anta att rekreationskonsumtion kommer att öka. Men leder detta i sin tur till fler problematiska konsumenter?

Svaret blir ja om man definierar begreppen på ett visst sätt. Om man anser att allt icke-medicinskt bruk av narkotika är missbruk blir det definitionsmässigt sant att missbruket har ökat i och med att rekreationskonsumtion har ökat. Men det är lättvindigt att reducera frågeställningen till att bara vara en fråga om definitioner. Man kan även komma fram till ett ja-svar med utgångspunkt $i$ viss teoribildning.

Grundläggande inom biokemisk teori (se Goldberg, 2011, kap. 2) är tanken att narkotikakonsumtion ger upphov till förändringar i det centrala nervsystemet som är av avgörande betydelse för individens beteende. Utifrån detta synsätt är det bara en tidsfråga innan drogkonsumenter blir "beroende", dvs. inte längre kan kontrollera sin konsumtion. Av detta följer att rekreationskonsumtion bör betraktas som en (snabbt) övergående fas. Dvs. med utgångspunkt i biokemisk teori har man anledning att befara att legalisering/avkriminalisering faktiskt kommer att leda till en väsentlig ökning av antalet problematiska konsumenter.

\section{Totalkonsumtionsteorin}

Totalkonsumtionsteorin (se t. ex. Bruun m.fl. 1975) bygger på studier av alkohol och framför ett antal teser. Teorins anhängare menar att:

- det finns ett empiriskt samband mellan per capita konsumtion och problematisk konsumtion, dvs. ju mer allmänheten dricker i genomsnitt, desto fler alkoholproblematiker,

- en tolerant attityd och lättillgänglighet ökar konsumtionen såväl hos normalkonsumenterna som hos problematiker,

- sociala normer som påbjuder låg konsumtion, samt juridiska och ekonomiska restriktioner som reglerar tillgången, reducerar totalkonsumtionen och därmed riskerna för problematisk konsumtion

- åtgärder som minskar normalkonsumentens drickande reducerar även problematikers konsumtion. En person med latenta tendenser till storkonsumtion dricker mindre i ett samhälle med låg konsumtion eftersom flertalet människor i hennes umgänge är måttlighetskonsumenter och dessas dryckesvanor motverkar överdrifter. Individen får helt enkelt mindre utrymme för att dricka.

- ökad tillgång leder till fler och allvarligare alkoholrelaterade skador.

Trots dessa resonemang har inte totalkonsumtionsteorin använts i någon större utsträckning för att propagera för prohibition. I stället har den legat till grund för den harm reduction-politik gentemot alkohol som fördes i Sverige under största delen av 1900-talet och som än idag påverkar vår alkoholpolitik.

Om man överför totalkonsumtionsteorin till narkotika är det rimligt att anta att det föreligger risk för att legalisering/avkri- 
minalisering kommer att leda till en reell ökning av antalet problematiska konsumenter. Men samtidigt säger totalkonsumtionsteorin att i vad mån så blir fallet är avhängigt vilka politiska åtgärder som vidtas och de sociala normer som utvecklas.

\section{Ytterligare faktorer}

Ytterligare faktorer som kan befaras bidra till att legalisering/avkriminalisering skulle innebära en dramatisk ökning av problematisk konsumtion kan tänkas vara:

- antagligen kommer fler att pröva olika droger och förmodligen kommer somliga av dessa att upptäcka att en viss drog passar deras syften väl,

- det blir relativt lätt att få tag på droger vilket kan bidra till att åtminstone en del människor som idag ligger i riskzonen för problematisk konsumtion kommer att gå över gränsen,

- somliga problematiska konsumenter som idag låter sig nöjas med alkohol och/eller legala läkemedel kan tänkas övergå till narkotika, eller lägga till narkotika till de substanser som de redan använder.

\section{Vad talar emot att legalisering/ avkriminalisering leder till en väsentlig ökning av problematisk konsumtion?}

Genom att betona psykosociala variabler får man en annan syn på droger och deras konsumenter jämfört med biokemiskt tänkande.

\section{Vad är problematisk konsumtion?}

I psykosocialt tänkande är rekreationskonsumtion och problematisk konsumtion två väsensskilda ting. Till skillnad från rekreationskonsumtion innebär problematisk konsumtion att alla de viktigaste livsområdena - levnadsförhållanden, fysisk hälsa, psykisk hälsa, sociala relationer, ekonomin, självbilden osv. - försämras. De allra flesta medborgare vill inte ha det så utan vill skapa ett bra liv åt sig och de sina. De finns helt enkelt få människor som är beredda att acceptera allt det negativa det medför att göra droger till den centrala aktiviteten i livet.

Problematiska konsumenter har svårt att se någon positiv framtid för egen del. Därför lever de för stunden och deras tänkande och handlande präglas vanligen av det (mycket) korta perspektivet. Mår man dåligt, vilket storkonsumenter oftast gör, och tar en drog som erbjuder tillfällig lindring, kan tolkningen bli att narkotika befrämjar ens liv. Man mår ju faktiskt bättre - för ögonblicket. Men om man betraktar de mera långsiktiga konsekvenserna i stället för stundens upplevelser, förstår man att narkotika inte gör livet bättre utan sämre. Med andra ord, för att vara problematisk konsument måste man leva bara i nuet - vilket långt ifrån alla medborgare skulle vilja eller ens kunna göra. De flesta av oss är helt enkelt skolade sedan barnsben till helt andra tankeoch beteendemönster. 


\section{Vem som helst blir inte problematisk konsument}

Problematiska konsumenter av narkotika är inte blott rekreationskonsumenter som "råkat bli beroende". Storkonsumenter har mycket säregna livserfarenheter med sig från tiden innan de började med droger. På grund av att de har haft så många oerhört negativa livserfarenheter upplever problematiska konsumenter att de står utanför samhället och att de är sämre än andra människor. Relativt få av oss känner så och utan denna starkt negativa självbild är man inte beredd att acceptera allt det destruktiva som livet som problematisk konsument för med sig.

Sett från motsatt håll har de allra flesta av oss en personlig historia som utgör ett psykosocialt skydd mot problematisk konsumtion. Vi har t.ex.:

- vuxit upp i en familj där det saknas extremt nedbrytande psykosociala relationer,

- fått en hyfsat positiv självbild,

- känt oss som en del av samhället,

- lärt oss att det är möjligt att skapa en positiv framtid,

- lärt oss tänka på lång sikt,

- inte blivit tillräckligt självdestruktiva för att finna livet på drogscenen meningsfullt, - inte upplevt narkotika som extremt positiv (om man prövat dessa substanser). Och även bland dem som uppskattar sina drogerfarenheter är det få som är beredda att offra sin familj, sitt jobb, sin trygghet, sin hälsa, sin självbild samt riskera att dö i förtid för att kunna få drogupplevelser, - lärt oss att inte betrakta kontinuerlig flykt som ett rimligt sätt att förhålla sig till livets prövningar,

- inget behov av att ta hämnd på familjen och/eller samhället.

Kort sagt, för att bli problematisk konsument av narkotika krävs en olycklig kombination av extremt negativa livserfarenheter, personlighetsegenskaper och biologiska anlag som relativt få torde ha. Ett tänkbart antagande är att de som riskerar att bli storkonsument av legala psykoaktiva substanser har redan funnit alkohol och/eller psykoaktiva läkemedel och därmed är inte en signifikant ökning av antalet problematiska konsumenter av psykoaktiva substanser att vänta ifall narkotika skulle legaliseras/ avkriminaliseras.

\section{Forskning}

Tvärtemot det som beroendeteori förutspår visar tillgänglig statistik att antalet problematiska konsumenter inte samvarierar med antalet rekreationskonsumenter. Under 1970-talet, och återigen på 1980talet, halverades antalet rekreationskonsumenter i Sverige. Samtidigt ökades nyrekryteringen till problematisk konsumtion under bägge årtionden. Och under 1990talet ökades både rekreationskonsumtion och problematisk konsumtion men den sistnämnda steg i betydligt snabbare takt. (Goldberg, 2010, s 317-320)

Och i motsats till det som den s.k. inkörsportsteorin förutsäger är det snarare ett ovanligt undantag och inte alls någon regel att en människa som använt cannabis blir problematisk konsument av andra 
droger. Nästan alla som har erfarenhet av narkotika i Sverige har inte prövat någon annan illegal drog än cannabis, och bara 4 $\%$ av människorna som prövat narkotika har blivit problematisk konsument av någon illegal drog. (a.a., s 318f)

Inget land har formellt legaliserat narkotika men en del länder har avkriminaliserat vissa droger och somliga länder har gått så långt att man kan säga att narkotikan de facto är legaliserad. Vad har detta lett till?

- i de länder där man avkriminaliserat cannabis finns en rad studier som visar att detta har små effekter på hur många som konsumerar och på intensiteten i konsumtionen. (se t.ex. Room m.fl., 2010, s 148, Hall \& Fischer, 2010, s 242f, MacCoun m.fl., 2009, s 368, Bretteville-Jensen \& Williams, 2010, s3)

- trots avkriminalisering av cannabis, och trots tillgång till cannabis i coffee shops och trots alla andra harm reduction-åtgärder som två generationer holländare levt med sedan barnsben, visar tillgänglig statistik att antalet problematiska konsumenter per capita i Nederländerna är på samma nivå som i Sverige. (Goldberg, 2005, s 31 lf) - efter en period då narkotikan var avkriminaliserad i Tjeckien kriminaliserades den på nytt, 1999. Men varken prevalens eller incidens minskade efter denna reform och lagstiftningen kom att betraktas som en oförsvarlig ekonomisk börda för polisen och domstolsväsendet. (Jelsma, 2011, s 10) Därför avkriminaliserades narkotikan åter vid årsskiftet 2008/09. 2009 fann man motstridiga effekter - problematisk konsumtion av metamfetamin men inte opiater ökade. Emellertid, ökningen av metam- fetamin till trots ligger antalet problematiska konsumenter per capita i Tjeckien på samma nivå som Sverige. (EMCDDA) - sju år efter det att Portugal avkriminaliserade all narkotika, inklusive heroin och kokain, visade en utvärdering att denna åtgärd "inte hade några ogynnsamma effekter på drogkonsumtionen - som i flertalet kategorier numera är bland de lägsta i EU." (Greenwald, 2009 s 1) Hughes \& Stevens (2010 s 1018) avslutar sin utvärdering av Portugals narkotikapolitik med att poängtera att "avkriminalisering av konsumtion och innehav av illegala droger inte nödvändigtvis innebär en ökning av drogrelaterade skador." Samtidigt tillägger de att den inte heller eliminerar alla drogrelaterade problem. (a.a.)

\section{Slutsats}

Att legalisering/avkriminalisering av narkotika skulle leda till en dramatisk ökning av problematisk konsumtion i Sverige är inte något som vi vet, utan är bara en åsikt som somliga tror på och driver. Men inte heller vet vi om motsatsen är sann - dvs. att det inte blir någon större skillnad om vi skulle legalisera/avkriminalisera. Bägge påståenden är bara hypoteser - inte bevisade fakta. I själva verket kan vi omöjligen veta vilket som är riktigt med mindre än att man legaliserar/avkriminaliserar under en period och gör vetenskapligt hållbara utvärderingar av det som händer. Med andra ord, för att kunna bygga vår narkotikapolitik på kunskap i stället för tro, måste vi experimentera med olika typer av aitgärder och sedan vetenskapligt utvärdera resultaten. Att göra 
så kännetecknar det som Campbell (1988) kallar "det experimenterande samhället". Några principer för det experimenterande samhället är:

1) beredvillighet att ifrågasätta egna "sanningar",

2) policybeslut betraktas som tillfälliga,

3) handling som forskning,

4) kunskap utvecklas ur osminkade utvärderingar, självkritik och att man tar till sig även obehagliga fakta,

5) öppenhet för nya idéer,

6) utvärderingar ska mäta såväl kortsiktiga som långsiktiga effekter. (a a)

Efter att man experimenterat med nya åtgärder används utvärderingarna som underlag för kommande narkotikapolitiska beslut.

Sverige tycks vara rädd för att ge sig ut i det okända utan klamrar sig fast i 80-talets narkotikapolitik. Vi varken experimenterar med nya åtgärder eller utvärderar det vi redan gör. Vi tycks vara tillfreds med vår tro om att vi är på rätt väg. Samtidigt har stora delar av världen förstått att prohibition medför väldigt många nackdelar och att vi bör pröva nya vägar. Här saknar Sverige egna erfarenheter och kan därmed inte bidra till förändringsprocessen. Dessutom tar vi sällan del av vad andra har gjort. Och de få gånger vi har tagit lärdom av andra, t.ex. sprutbyte, förhalas införandet av nya åtgärder så länge som möjligt.

Tiden är mer än mogen för en genomgripande omprövning av hela vårt tänkande kring narkotika. Snarare än att vara ett föregångsland, som vi så gärna vill tro att vi är, är Sverige på god väg att förpassas till narkotikapolitikens utmarker.

\section{Referenser}

Bretteville-Jensen, A L \& Williams, J (2010): Decriminalization and initiation into cannabis use. Paper presenterad vid Fourth Annual Conference of the International Society for the Study of Drug Policy, Santa Monica, CA.

Bruun, K, Edwards, G, Lumio, M, Mäkelä, K, Pan, L, Popham, R E, Room, R, Schmidt, W, Skog, O-J, Sulkunen, P \& Österberg, E (1975): Alcohol control policies in public health perspective. The Finnish foundation for alcohol studies, vol 25, Aurassen Kirjapainoi, Forssa.

Campbell, D T (1988): The experimenting society, i Overman, E S (ed) - Methodology and epistemology for social science. selected papers, Univ. of Chicago Press, Chicago.
Duff, C (2008): The pleasure in context, International journal of drug policy. 19:5, s 384-92.

EMCDDA (European Monitoring Centre for Drugs and Drug Addiction) (2011): Statistics and country data, Country overviews, Czech Republic. http://www.emcdda.europa.eu/ publications/country-overviews/cz\#pdu

Fingarette, H (1989): Heavy drinking: The myth of alcoholism as a disease. Univ. of California press, Berkeley.

Goldberg, T (2011): Legalisera narkotika? - Ett diskussionsunderlag. Academic publishing of Sweden, Solna.

Goldberg, T (2010): Hur blir man narkoman? Och hur hindrar vi det. Academic publishing of 


\section{Sweden, Solna.}

Goldberg, T (2005): Samhället i narkotikan. Academic publishing of Sweden, Solna.

Greenwald, G (2009): Drug decriminalization in Portugal: Lessons for creating fair and successful drug policies. Cato institute, Washington, D.C. http://www.cato.org/pub_display.php?pub_ id $=10080$

Hall, W \& Fischer, B (2010); Harm reduction policies for cannabis, i Rhodes, T \& Hedrich, D, Harm reduction: evidence, impacts and challenges. EMCDDA monograph series No 10. http:// www.emcdda.europa.eu/attachements.cfm/ att_101257_EN_EMCDDA-monograph 10harm\%20reduction_final.pdf

Hughes, C E \& Stevens, A (2010): What can we learn from the Portuguese decriminalization of illicit drugs?, British Journal of Criminology. 50, s 999-1022.

Jelsma, M (2011): The development of international drug controll: Lessons learned and strategic challenges for the future. Working paper prepa- red for Global Commission on Drug Policies meeting, Geneva, 24-25 Januari 2011, http:// idpc.net/sites/default/files/library/Development-international-drug-control.pdf

Latin American Commission on Drugs and Democracy (2010): Drugs and democracy: Toward a paradigm shift. http://www.drogasedemocracia.org/Arquivos/declaracao_ingles_site.pdf

MacCoun, R J, Pacula, R L, Chriqui, J, Harris, K \& Reuter, $P$ (2009): Do citizens know whether their state has decriminalized marijuana? Assessing the perceptual component of deterrence theory, Review of Law and Economics, 5:1, Article 15, s 347-371.

Peele, S (1998): The meaning of addiction: An unconventional view. Jossey-Bass Publishers, San Francisco.

Room, R, Fischer, B, Hall, W, Lenton, S \& Reuter, P (2010): Cannabis policy: Moving beyond stalemate. Beckley Foundation Press \& Oxford University Press, Oxford. 